\title{
PEMBANGUNAN DATABASE DESTINASI PARIWISATA INDONESIA Pengumpulan dan Pengolahan Data Tahap I
}

\author{
Yosafati Hulu \\ Information Systems Department, School of Information Systems, Binus University \\ Jl. K.H. Syahdan No. 9, Palmerah, Jakarta Barat 11480 \\ yosahulu@yahoo.com
}

\begin{abstract}
Considering the increasing need for local (government and community) in developing tourism destinations in the era of autonomy, considering the need to select the appropriate attraction according to the respective criteria, and considering the needs of businessmen travel / hotel to offer the appropriate attraction with the needs of potential tourists, it is necessary to develop a database of tourist destinations in Indonesia that is able to facilitate these needs. The database is built is a web-based database that is widely accessible and capable of storing complete information about Indonesian tourism destination as a whole, systematic and structured. Attractions in the database already classifiable based attributes: location (the name of the island, province, district), type/tourism products, how to achieve these attractions, the cost, and also a variety of informal information such as: the ins and outs of local attractions by local communities or tourists. This study is a continuation of previous studies or research phase two of three phases planned. Phase two will focus on the collection and processing of data as well as testing and refinement of the model design and database structure that has been created in Phase I. The study was conducted in stages: 1) Design Model and Structure Database, 2) Making a Web-based program, 3) Installation and Hosting, 4) Data Collection, 5) Data Processing and Data entry, and 6) Evaluation and improvement/Completion.
\end{abstract}

Keywords: Travel, Destinations, Database

\begin{abstract}
ABSTRAK
Mengingat adanya peningkatan kebutuhan daerah (pemerintah dan masyarakat) dalam mengembangkan destinasi pariwisata di era otonomi dan pemekaran wilayah dibandingkan di era sebelumnya, mengingat adanya kebutuhan untuk memilih dengan tepat objek wisata sesuai dengan kriterianya masingmasing, dan mengingat adanya kebutuhan pengusaha travel/hotel untuk menawarkan objek-objek wisata sesuai dengan kebutuhan calon wisatawan, maka perlu dikembangkan suatu database destinasi wisata di Indonesia yang mampu memfasilitasi kebutuhan-kebutuhan tersebut. Database yang dibangun adalah database berbasis web yang dapat diakses secara luas dan mampu menyimpan informasi lengkap tentang destinasi pariwisata Indonesia secara menyeluruh, sistematis dan terstruktur. Objek wisata dalam database tersebut sudah terklasifikasikan berdasarkan atribut: lokasi (nama pulau, propinsi, kabupaten), jenis/produk wisata, bagaimana mencapai objek wisata tersebut, biaya, dan juga berbagai informasi informal seperti: seluk beluk objek wisata daerah berdasarkan masyarakat lokal atau wisatawan. Penelitian ini merupakan lanjutan penelitian sebelumnya atau penelitian Tahap Kedua dari tiga tahap yang telah direncanakan. Tahap Kedua akan fokus pada pengumpulan dan pengolahan data serta pengujian dan penyempurnaan rancangan model dan struktur database yang telah dibuat pada Tahap I. Penelitian dilakukan secara bertahap: 1) Perancangan Model dan Struktur Database, 2) Pembuatan Program berbasis Web, 3) Instalasi dan Hosting, 4) Pengumpulan Data, 5) Pengolahan Data dan Entri Data, dan 6) Evaluasi serta Perbaikan/Penyempurnaan.
\end{abstract}

Kata kunci: Wisata, Destinasi, Database 


\section{PENDAHULUAN}

Jumlah Destinasi Pariwisata di Indonesia di era otonomi mengalami pertumbuhan yang signifikan. Masing-masing daerah otonom atau daerah pemerintahan baru berupaya mencari dan mengembangkan potensi wisata supaya bisa dijual untuk menambah PAD (Pendapatan Asli Daerah) dan meningkatkan ekonomi masyarakat (Care Tourism, 2010). Pembangunan sistem database akan mempermudah penyajian destinasi wisata beserta produknya kepada calon-calon wisatawan. Tanpa database yang lengkap dan terintegrasi akan membuat calon wisatawan atau pengusaha yang bergerak dalam industri pariwisata mengalami kesulitan dalam mengetahui dan mengenal dengan lengkap destinasi pariwisata Indonesia dan produk-produknya (Rahardjo, Budi, 2004).

Hal-hal tersebut di atas yang menjadi alasan mengapa perlu dibangun suatu sistem database yang mendukung (sekaligus menjembatani) kebutuhan daerah untuk menyajikan dan mempromosikan objek wisata beserta produk-produknya dan kebutuhan wisatawan dan kalangan pengusaha untuk menemukan dengan mudah objek wisata yang diinginkan di antara ribuan objek wisata yang tersebar di wilayah Indonesia.

Database yang akan dibangun adalah database berbasis web yang dapat diakses secara luas melalui internet. Sistem ini mampu menyimpan dan menyajikan baik informasi formal (yang dilakukan melalui pengumpulan data primer/sekunder) maupun informasi informal (seperti seluk beluk objek wisata daerah, yang dimasukkan oleh masyarakat lokal atau oleh wisatawan berdasarkani pengalamannya sendiri). Database ini akan dibangun dalam beberapa tahap dan dilakukan secara berkesinambungan sehingga menjadi database yang lengkap dan efektif dalam membantu pengembangan destinasi pariwisata di Indonesia.

Secara umum, ada tiga tujuan utama yang ingin dicapai dengan pembangunan sistem database ini: (1) Adanya database yang mampu digunakan untuk merekam dan menyajikan seluruh destinasi pariwisata di Indonesia secara rinci. (2) Adanya sistem yang mampu melibatkan langsung masyarakat lokal dalam menyajikan berbagai hal tentang destinasi pariwisata di daerah. (3) Adanya database yang mampu menerima berbagai informasi tentang pengalaman wisatawan dalam mengunjungi objek wisata tertentu. (4) Adanya database yang berisi kurang lebih 140 destinasi pariwisata di Indonesia sehingga bisa digunakan oleh berbagai kalangan yang membutuhkannya.

Penelitian ini penting dilakukan karena: (1) Ada peningkatan kebutuhan daerah (pemerintah dan masyarakat) untuk mengembangkan destinasi pariwisata di era otonomi dan pemekaran wilayah. (2) Ada kebutuhan masyarakat (wisatawan) untuk memilih dengan tepat objek wisata sesuai dengan kriterianya masing-masing. (3) Ada kebutuhan pengusaha travel/hotel untuk menawarkan objek wisata yang menarik, sementara sistem yang memfasilitasi kebutuhan-kebutuhan tersebut belum ada. (4) Terjadinya era pemerataan tujuan wisata sehingga tercipta suatu kondisi yang memudahkan para wisatawan baik lokal maupun internasional mengunjungi atau melakukan riset. (5) Melanjutkan penelitian awal yang telah dilakukan sehingga berkelanjutan dan menghasilkan sistem informasi yang berguna bagi industri pariwisata di Indonesia.

Manfaat-manfaat yang diperoleh dapat dijelaskan pada sebagai berikut ini: (1) Manfaat bagi Masyarakat - Pertama, membantu masyarakat dalam memilih tujuan wisata yang sesuai dengan minat dan anggarannya. Kedua, membantu masyarakat untuk bisa mengunjungi beberapa objek wisata yang berdekatan secara berurutan karena ketersediaan informasi objek wisata yang berdekatan satu dengan yang lain. Ketiga, membantu masyarakat menyampaikan secara langsung pengalaman dalam mengunjungi objek wisata tertentu sehingga menjadi umpan balik bagi yang berkepentingan dan referensi bagi calon wisatawan yang lain. Keempat, membantu masyarakat untuk mempromosikan secara langsung objek wisata yang ada di daerahnya sendiri, termasuk informasi yang relevan seperti: 
produk wisata, fasilitas, dan cara mencapai lokasi. Kelima, membantu meningkatkan pendapatan masyarakat daerah karena memungkinkan mereka secara langsung dapat mempromosikan destinasi wisata yang ada daerahnya masing-masing. (2) Manfaat bagi Pengusaha - Pertama, membantu pengusaha khususnya yang bergerak dalam bidang tour, travel, dan hotel untuk memperluas pangsa pasar dan memperbanyak produk-produk yang ditawarkan. Kedua, membantu pengusaha dalam mempromosikan bidang usaha dan produknya. Ketiga, mengurangi biaya promosi serta membuka pasar internasional atas potensi wisata di Indonesia. (3) Manfaat bagi Pemerintah - Pertama, membantu pemerintah daerah dalam pencapaian target jumlah wisatawan di daerahnya karena database ini bisa menjadi sarana informasi, komunikasi, dan promosi destinasi wisata pemerintah daerah. Kedua, membantu tercapainya sasaran pengembangan ekonomi kreatif yang dicanangkan oleh pemerintah (4) Manfaat bagi Akademis - Pertama, sebagai sarana yang efektif dalam mengembangkan dan menerapkan bidang ilmu sistem informasi untuk kepentingan masyarakat, pengusaha, dan instansi pemerintah secara real. Kedua, sebagai dasar dalam penelitian, pengembangan, dan penerapan bidang ilmu lain seperti: Data Warehouse, Decision Support System, dan Expert System bagi industri pariwisata Indonesia.

\section{METODE}

\section{Hasil Studi Pustaka: Jurnal, Artikel, dan Website atau Portal Pariwisata}

Hasil Studi Pustaka dari berbagai jurnal, artikel, dan website atau portal pariwisata di internet, dapat diuraikan sebagai berikut: (1) Belum ada database yang terintegrasi tentang destinasi pariwisata di Indonesia secara menyeluruh, yang ada baru per daerah atau per objek wisata. (2) Belum ada sistem yang memungkinkan secara langsung melibatkan potensi dan sumber daya lokal dalam memasukkan berbagai informasi objek wisata di wilayahnya sendiri. Padahal “... pentingnya keterlibatan warga dalam mengembangkan destinasi pariwisata” (Pangestu, 2011) belum ada sistem database yang memudahkan wisatawan mencari objek wisata di Indonesia berdasarkan atribut: lokasi (nama pulau, propinsi, kabupaten), jenis/produk wisata, bagaimana mencapai objek tersebut, biaya, dan juga berbagai informasi informal seperti: seluk beluk objek wisata daerah yang di-input oleh masyarakat lokal atau berbagai infromasi pengalaman wisata yang diinput oleh wisatawan itu sendiri.

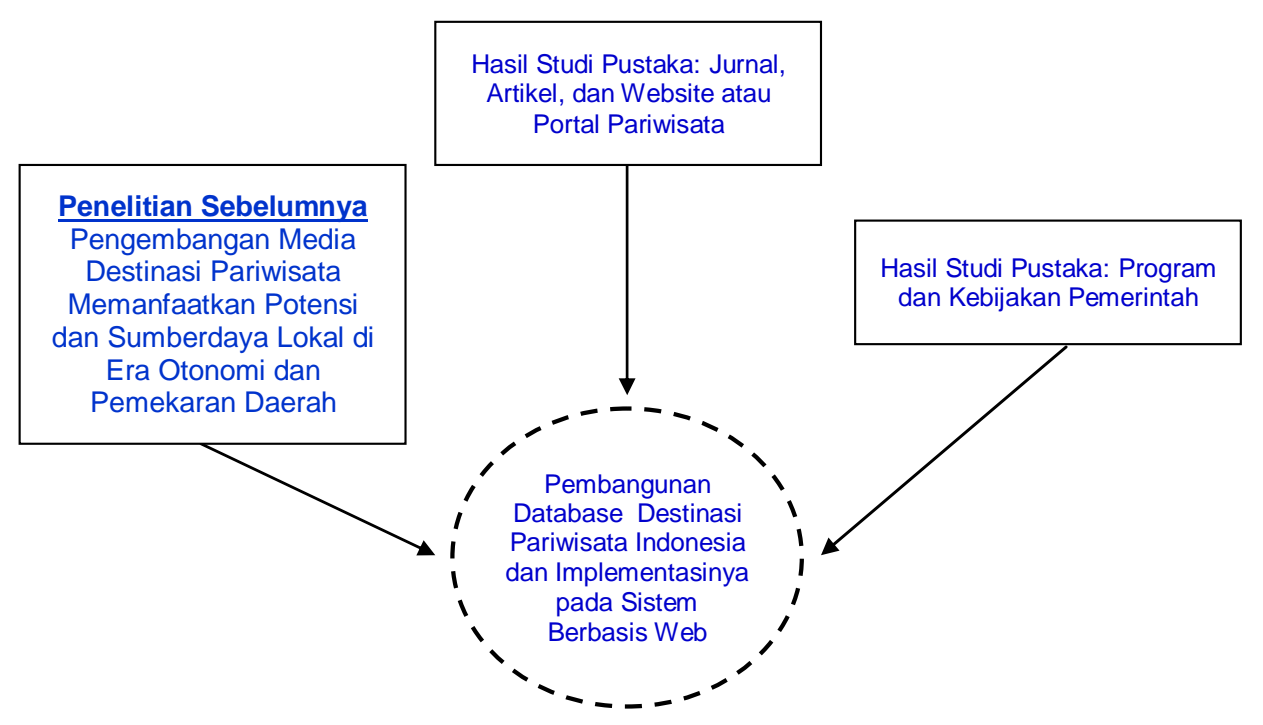

Gambar 1 Hasil Studi Pustaka 


\section{Hasil Studi Pustaka: Program dan Kebijakan Pemerintah}

Hasil Studi Pustaka yang dilakukan pada: "Visi Pengembangan Destinasi Pariwisata Indonesia”, "Rencana Pengembangan Ekonomi Kreatif Indonesia 2009-2025”, “Rencana Strategis Kementerian Pariwisata dan Ekonomi Kreatif", "Pemanfaatan Teknologi Informasi dalam Promosi Destinasi Wisata", dan "Pengembangan Destinasi Wisata Harus Libatkan Warga", adalah perlu dibangun suatu database yang lengkap dan terintegrasi serta fleksibel untuk mendukung program dan kebijakan pemerintah (Departemen Perdagangan Republik Indonesia, 2008)

\section{Hasil Studi Pustaka: Pengembangan Media Destinasi Pariwisata Memanfaatkan Potensi dan Sumberdaya Lokal di Era Otonomi dan Pemekaran Daerah}

Hasil Studi Pustaka pada hasil penelitian sebelumnya tentang "Pengembangan Media Destinasi Pariwisata Memanfaatkan Potensi dan Sumberdaya Lokal di Era Otonomi dan Pemekaran Daerah" adalah perlu dilakukan penelitian lebih lanjut dan lebih fokus pada pembangunan database destinasi pariwisata di Indonesia. Database yang telah berisi informasi sekitar 140 destinasi pariwisata Indonesia akan mendorong pengguna untuk memanfaatkan dan melengkapi media tersebut. Kelengkapan data dan informasi adalah salah satu tujuan pada penelitian kali ini.
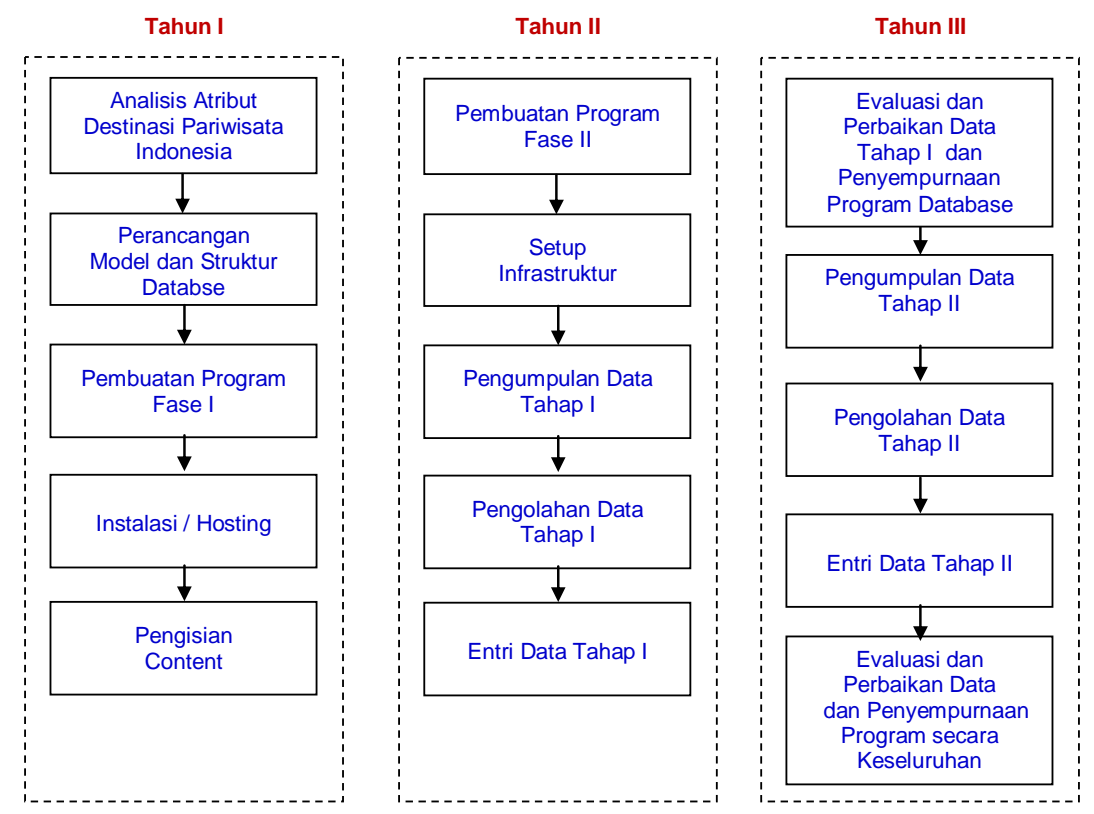

Gambar 2 Tahapan Penelitian

\section{Tahapan Penelitian}

Tahapan Penelitian "Pembangunan Database Destinasi Pariwisata Indonesia dan Implementasinya pada Sistem Berbasis Web" dilakukan secara bertahap seperti yang dijelaskan pada Gambar 2. Gambar 2 membagi tiga kelompok pekerjaan yaitu: (1) Pekerjaan yang dilakukan pada Tahun I. (2) Pekerjaan yang dilakukan pada Tahun II. (3) Pekerjaan yang dilakukan pada Tahun III. Dengan tahapan penelitian ini maka setiap akhir tahun dapat menghasilkan laporan penilitian untuk dievaluasi dan diperbaiki pada penelitian tahun berikutnya. Beberapa Tahapan Penelitian di atas akan dijelaskan secara rinci di bawah ini. 


\section{HASIL DAN PEMBAHASAN}

\section{Perancangan Model Database}

Pada tahap ini akan dirancang model database yang tepat supaya bisa menyimpan, menyajikan, dan mencari informasi objek wisata di seluruh Indonesia. Atribut objek wisata akan dipelajari lewat jurnal, buku, atau informasi di internet (website yang berkaitan dengan objek wisata) kemudian atribut tersebut dirumuskan untuk menghasilkan model database yang mengakomodir seluruh informasi yang diperlukan. Database yang dibangun harus mampu menerima informasi dari berbagai kalangan berdasarkan hak otoritas yang diberikan. Oleh karena itu, User Interface, Hak Otoritas User, dan Struktur Menu dirancang sedemikian rupa sehingga penempatan informasi oleh pengguna dapat diarahkan sesuai dengan struktur, klasifikasi, dan atribut objek-objek wisata.

Perancangan Model Database dapat dilihat pada Gambar 3 di bawah ini (Neeraj, 2010)

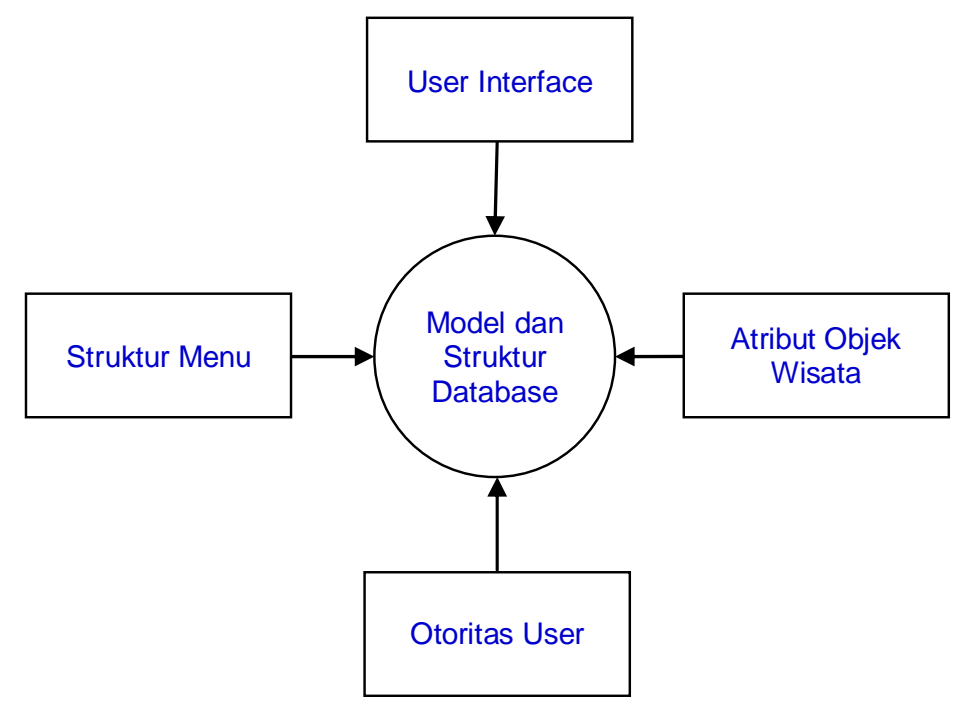

Gambar 3 Rancangan Model dan Struktur Database

\section{Atribut Objek Wisata}

Informasi Objek Wisata dapat dibagi dua, yaitu: Informasi Utama dan Informasi Tambahan. Informasi Utama adalah informasi yang menjelaskan tentang objek wisata itu sendiri sedangkan Informasi Tambahan adalah informasi yang relevan dengan objek wisata tersebut dan dapat dimasukkan oleh setiap user.

Atribut utama dapat dilihat pada Tabel 1. Atribut ini bisa berkembang disesuikan dengan kebutuhan setelah tahap implementasi (Silberschatz, 2005). 
Tabel 1 Atribut Objek Wisata

\begin{tabular}{cl}
\hline No & Nama Atribut \\
\hline 1. & Nama Objek Wisata \\
2. & Lokasi Objek Wisata \\
& $\bullet \quad$ Propinsi \\
& $\bullet \quad$ Kabupaten/Kota \\
& $\bullet \quad$ Kecamatan \\
3. & Bagaiman Mencapai Lokasi \\
4. & Fasilitas Umum yang Tersedia \\
5. & Hal-Hal yang Diperhatikan oleh Pengunjung \\
6. & Kategori Objek Wisata \\
7. & Produk Wisata \\
8. & Lampiran: Foto, Dokumen, atau Link \\
9. & Informasi Tambahan dari Masyarakat Lokal atau Pengalaman \\
& Wisatawan/Pengunjung \\
\end{tabular}

\section{Rancangan Database}

Struktur Tabel-Tabel utama yang digunakan dapat dilihat pada tabel berikut. Strukur ini merupakan hasil akhir dari proses optimalisasi yang dilakukan berdasarkan atribut utama objek wisata yang telah ditentukan pada pembahasan sebelumnya. Jenis Field (Field Type) akan disesuaikan dengan sintaks MySql sebagai database yang akan digunakan dalam pembuatan media ini.

Tabel 2 Objek Wisata

\begin{tabular}{|c|c|c|c|c|}
\hline No & Nama Field & Jenis & $\mathbf{M} / \mathbf{O}$ & Keterangan Singkat \\
\hline 1. & OW_KODE & CHAR (8) & M & Kode Objek Wisata \\
\hline 2. & $\overline{\text { OW_NAMA }}$ & VARCHAR (80) & M & Nama Objek Wisata \\
\hline 3. & OW_NAMA_LL & VARCHAR (80) & $\mathrm{O}$ & $\begin{array}{l}\text { Nama Lain / Populer dari Objek } \\
\text { Wisata }\end{array}$ \\
\hline 4. & PRO_KODE & CHAR(2) & M & $\begin{array}{l}\text { Lokasi Objek Wisata (Kode } \\
\text { Propinsi) }\end{array}$ \\
\hline 5. & KAB_KODE & CHAR(4) & M & $\begin{array}{l}\text { Lokasi Objek Wisata (Kode } \\
\text { Kabupaten/Kota) }\end{array}$ \\
\hline 6. & KEC_KODE & CHAR(8) & M & $\begin{array}{l}\text { Lokasi Objek Wisata (Kode } \\
\text { Kecamatan) }\end{array}$ \\
\hline 7. & DES_KODE & CHAR(8) & M & Lokasi Objek Wisata (Kode Desa) \\
\hline 8. & DESKRIPSI & TEXT & M & Deskripsi Objek Wisata \\
\hline 9. & CARA_MENCAPAI & TEXT & M & $\begin{array}{l}\text { Bagaimana mencapai lokasi Objek } \\
\text { Wisata }\end{array}$ \\
\hline 10. & FASILITAS & TEXT & M & Fasilitas umum yang tersedia \\
\hline 11. & HAL_PERHATIAN & TEXT & M & Hal-hal yang perlu diperhatikan \\
\hline 12. & STATUS & CHAR(1) & M & $\begin{array}{l}\text { Status (N: Belum diotorisasi, Y: } \\
\text { Sudah diverifikasi) }\end{array}$ \\
\hline
\end{tabular}

Tabel ini adalah tabel utama yang menyimpan informasi utama tentang objek-objek wisata atau destinasi pariwisata. 
Tabel 3 OW_OW (Tabel Hubungan Objek Wisata dengan Objek Wisata Lain)

\begin{tabular}{|c|c|c|c|c|}
\hline No & Nama Field & Jenis & $\mathbf{M} / \mathbf{O}$ & Keterangan Singkat \\
\hline 1. & OW_KODE & CHAR (8) & M & Kode Objek Wisata \\
\hline 2. & OW_KODE_DKT & CHAR (8) & M & Objek Wisata yang berdekatan \\
\hline 3. & JARAK_KM & MEDIUMINT & M & $\begin{array}{l}\text { Jarak (KM) antara objek wisata } \\
\text { terdekat }\end{array}$ \\
\hline 4. & WAKTU_TEMPUH & & M & $\begin{array}{l}\text { Waktu Tempuh (Jam:Menit) antara } \\
\text { objek wisata terdekat }\end{array}$ \\
\hline 5. & WAKTU_TEMPUH_DGN & CHAR(1) & M & $\begin{array}{l}\text { Waktu Tempuh dengan apa? Mis: } \\
\text { Pesawat, Kereta Api, Mobil, } \\
\text { Sepeda Motor, atau Jalan Kaki }\end{array}$ \\
\hline 6. & STATUS & CHAR(1) & M & $\begin{array}{l}\text { Status (N: Belum diotorisasi, Y: } \\
\text { Sudah diverifikasi) }\end{array}$ \\
\hline
\end{tabular}

Tabel yang menghubungkan antara objek wisata dengan objek wisata yang lain. Tabel ini berguna bagi calon wisatawan untuk mengetahui objek wisata apa saja yang berdekatan dengan objek wisata tertentu sehingga bisa digunakan sebagai referensi atau bantuan dalam memutuskan apakah mau mengunjungi lokasi-lokasi tersebut secara bersamaan atau tidak.

Tabel 4 KATEGORI (Kategori Objek Wisata)

\begin{tabular}{cllcl}
\hline No & Nama Field & Jenis & M/O & Keterangan Singkat \\
\hline 1. & KATEGORI_KODE & CHAR (2) & M & Kode Kategori Objek Wisata \\
2. & KATEGORI_NAMA & VARCHAR (20) & M & Nama Kategori Objek Wisata \\
3. & STATUS & CHAR(1) & M & Status (N: Belum diverifikasi, Y: Sudah \\
& & & & diverifikasi) \\
\hline
\end{tabular}

Tabel yang menyimpan daftar kategori objek wisata.

Tabel 5 OW_KATEGORI (Objek Wisata dan Kategorinya)

\begin{tabular}{cllcl}
\hline No & Nama Field & Jenis & M/O & Keterangan Singkat \\
\hline 1. & OW KODE & CHAR (8) & M & Kode Objek Wisata \\
2. & KATEGORI_KODE & CHAR (2) & M & Kode Kategori Objek Wisata \\
3. & KETERANGAN & TINYTEXT & O & Keterangan Tambahan kalau ada \\
4. & STATUS & CHAR(1) & M & $\begin{array}{l}\text { Status (N: Belum diverifikasi, Y: Sudah } \\
\text { diverifikasi) }\end{array}$ \\
\hline
\end{tabular}

Tabel yang menyimpan kategori objek wisata. Dengan adanya tabel ini maka objek wisata dapat dikelompokkan dalam beberapa kategori sehingga memudahkan dalam perekaman dan penyajian objek wisata.

Tabel 6 PRODUK (Objek Wisata dan Produknya)

\begin{tabular}{cllcl}
\hline No & Nama Field & Jenis & M/O & Keterangan Singkat \\
\hline 1. & PRODUK_KODE & CHAR (4) & M & Kode Produk Wisata \\
2. & PRODUK_NAMA & TINYTEXT & M & Nama Produk Wisata \\
3. & STATUS & CHAR(1) & M & Status (N: Belum diverifikasi, Y: Sudah \\
& & & & diverifikasi) \\
\hline
\end{tabular}

Tabel yang menyimpan daftar produk objek wisata. 
Tabel 7 OW_PRODUK (Objek Wisata dan Kategorinya)

\begin{tabular}{cllcl}
\hline No & Nama Field & Jenis & M/O & Keterangan Singkat \\
\hline 1. & OW_KODE & CHAR (8) & M & Kode Objek Wisata \\
2. & PRODUK_KODE & CHAR (4) & M & Kode Produk Wisata \\
3. & KETERANGAN & TINYTEXT & O & Keterangan Tambahan kalau ada \\
4. & STATUS & CHAR(1) & M & $\begin{array}{l}\text { Status (N: Belum diverifikasi, Y: Sudah } \\
\text { diverifikasi) }\end{array}$ \\
& & & \\
\hline
\end{tabular}

Tabel yang menyimpan produk apa saja yang ada pada objek wisata tertentu. Dengan adanya tabel ini maka objek wisata dapat memiliki beberapa produk objek wisata sehingga memudahkan dalam perekaman dan penyajian objek wisata.

Tabel 8 LAMP (Lampiran atau attachment)

\begin{tabular}{cllcl}
\hline No & Nama Field & Jenis & M/O & Keterangan Singkat \\
\hline 1. & LAMP_CODE & CHAR (8) & M & Kode Lampiran \\
2. & LAMP_JUDUL & VARCHAR (80) & M & Judul Lampiran \\
2. & LAMP_DESKRIPSI & TEXT & M & Deskripsi Lampiran \\
2. & LAMP_ALM & TINYTEXT & M & Alamat Lampiran disimpan \\
3. & LAMP_JNS & CHAR(1) & M & Jenis Lampiran: Foto, Dokumen, atau Link \\
4. & LAMP_TGL & DATE & M & Tanggal Lampiran \\
5. & LAMP_REF & TINYTEXT & M & Referensi/Sumber Lampiran \\
6. & STATUS & CHAR(1) & M & Status (N: Belum diverifikasi, Y: Sudah \\
& & & & diverifikasi)
\end{tabular}

Tabel Lampiran berguna untuk menyimpan alamat lampiran (foto, dokumen, dan link) disimpan (di-attach). Tabel ini bisa digunakan oleh tabel-tabel lain dengan mengaitkannya dengan field LAMP_CODE.

Tabel 9 OW_LAMP (Lampiran Objek Wisata)

\begin{tabular}{cllcl}
\hline No & Nama Field & Jenis & M/O & Keterangan Singkat \\
\hline 1. & OW_KODE & CHAR (8) & M & Kode Objek Wisata \\
2. & LAMP_CODE & CHAR (8) & M & Kode Lampiran \\
\hline
\end{tabular}

Tabel ini merupakan relasi antara Tabel OW dengan Tabel LAMP. Dengan adanya tabel ini maka informasi utama tentang objek wisata bisa disertai dengan foto, dokumen, dan link sebagai pendukung informasi utama.

Tabel 10 INFO (Informasti Tambahan Objek Wisata)

\begin{tabular}{cllcl}
\hline No & Nama Field & Jenis & M/O & Keterangan Singkat \\
\hline 1. & OW KODE & CHAR (8) & M & Kode Objek Wisata \\
2. & INFO_KODE & CHAR (8) & M & Kode Informasi Tambahan \\
3. & INFO_NARASI & TEXT & M & Informasi yang dimasukkan \\
4. & INFO_WAKTU & DATETIME & M & Waktu info diinput atau waktu upload \\
5. & INFO_SUMBER & TINYTEXT & M & Sumber Informasi Tambahan \\
6. & STATUS & CHAR(1) & M & Status (N: Belum diverifikasi, Y: Sudah diverifikasi) \\
\hline
\end{tabular}

Tabel di atas berisi informasi yang relevan dengan objek wisata dan bisa dimasukkan oleh setiap orang yang terlibat. Misalnya informasi tambahan yang dimasukkan oleh masyarakat lokal tentang objek wisata di daerahnya atau informasi tentang pengalaman wisatawan yang terkait dengan objek wisata yang bersangkutan. 
Tabel 11 INFO_LAMP (Informasti Tambahan Objek Wisata)

\begin{tabular}{cllcl}
\hline No & Nama Field & Jenis & M/O & Keterangan Singkat \\
\hline 1. & OW_KODE & CHAR (8) & M & Kode Objek Wisata \\
2. & INFO_KODE & CHAR (8) & M & Kode Informasi Tambahan \\
3. & LAMP_CODE & CHAR (8) & M & Kode Lampiran \\
\hline
\end{tabular}

Tabel relasi antara Tabel INFO dengan Tabel LAMP. Dengan adanya tabel ini maka informasi tambahan bisa disertai dengan foto, dokumen, dan link sebagai pendukung informasi tambahan.

\section{Pembuatan Program berbasis Web}

Program Database yang akan dibuat harus menghasilkan sistem yang mudah digunakan oleh berbagai kalangan (Proll, Birgit and Retschitzegger, Werner, 2008) dengan memenuhi kriteria sebagai berikut: (1) Bahasa Pemrogram dan Database yang dipergunakan dalam pembuatan sistem ini harus berbasis web supaya bisa diimplentasikan di internet sehingga mudah diakses secara luas oleh setiap pengguna. (2) User Interface merupakan hal paling utama diperhatikan sehingga masyarakat lokal bisa memasukkan dengan mudah berbagai informasi yang berhubungan dengan objek wisata di daerahnya dan sebaliknya calon wisatawan bisa mencari dengan mudah objek wisata yang dibutuhkannya dengan memasukan atau memilih dari berbagai atribut. (3) Program juga harus dibuat modular dan fleksibel supaya mudah dalam penambahan dan penyempurnaan pada setiap tahapan penelitian yang telah dibagi dalam tiga tahun. (4) Program Aplikasi yang dibuat harus diuji coba dulu di server lokal untuk menghilangkan atau memperkecil kesalahan-kesalahan atau bug yang mungkin terjadi setelah diterapkan atau di-instal jaringan yang lebih luas (internet).

\section{Instalasi dan Hosting}

Implementasi diawali dengan mendaftarkan nama domain yang singkat, mudah ditulis, dieja dan didengar, serta menggambarkan informasi tentang destinasi pariwisata di Indonesia. Selanjutnya melakukan penyewaan server (hosting) kepada pihak ketiga atau operator yang handal dan bisa dipercaya dengan harga sewa yang ekonomis. Konfigurasi server yang diperlukan juga disesuaikan dengan kebutuhan secara bertahap. Setelah pendaftaran nama domain dan penyewaan server dilakukan, program aplikasi yang telah dibuat akan di-install di server yang telah disewa supaya sistem bisa aktif dan siap digunakan oleh semua kalangan pengguna sesuai dengan hak otoritas yang telah ditentukan.

\section{Pengumpulan Data}

Metoda pengumpulan data dilakukan dengan dua cara yaitu: pengumpulan data primer dan pengumpulan data sekunder. Tujuannya untuk memperoleh data seperti pada Tabel 12. Pengumpulan data primer dilakukan dengan survei langsung dengan mendatangi lokasi objek wisata. Kegiatan yang dilakukan adalah pemotretan produk wisata, melakukan wawancara dengan wisatawan dan penduduk lokal, serta mencatat hal-hal yang diperlukan seperti yang telah dijelaskan pada Tabel 1. Pengumpulan data sekunder dilakukan dengan penelusuran informasi dari berbagai sumber dengan tujuan memperoleh data seperti yang telah dijelaskan pada Tabel 1. 
Tabel 12 Data yang Diperlukan

\begin{tabular}{cl}
\hline No & Jenis Kegiatan \\
\hline 1 & Nama objek wisata \\
2 & Nama lain atau nama populer dari objek wisata tersebut (kalau ada) \\
3 & Deskripsi objek wisata \\
4 & Lokasi (propinsi, kabupaten/kota, kecamatan, desa \\
5 & Cara untuk mencapai lokasi objek wisata \\
6 & Gambar/foto pendukung \\
7 & Dokumen pendukung \\
8 & Komentar atau pengalaman wisatawan atau pengalaman sendiri selama \\
\end{tabular}

\section{Pengolahan dan Entri Data}

Data yang telah terkumpul akan diolah dan disesuaikan dengan kebutuhan untuk di-entry di dalam database sehingga menghasilkan Database Destinasi Pariwisata Indonesia yang lengkap. Gambar 4 adalah form utama dalam proses entry data sedangkan sedangkan Gambar 5 adalah Tampilan Daftar Objek Wisata dan Form Pencarian

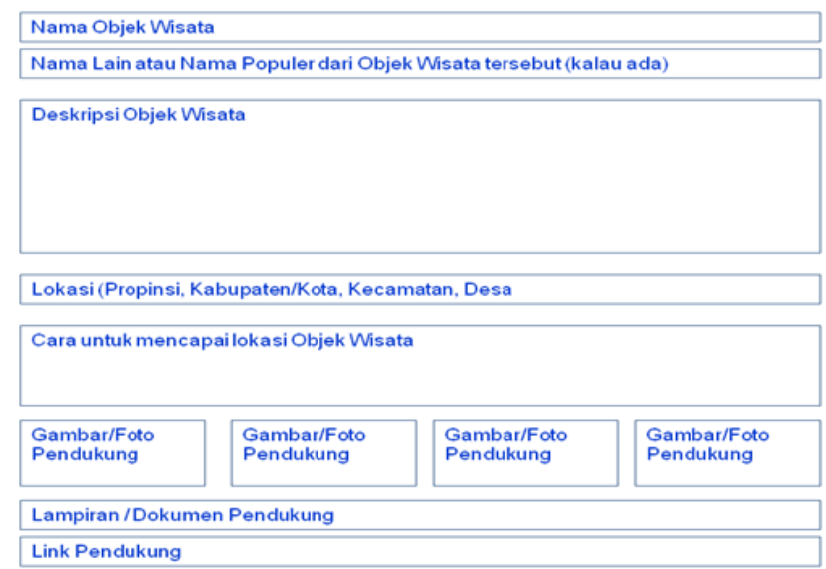

Gambar 4 Form Utama untuk Entry Data

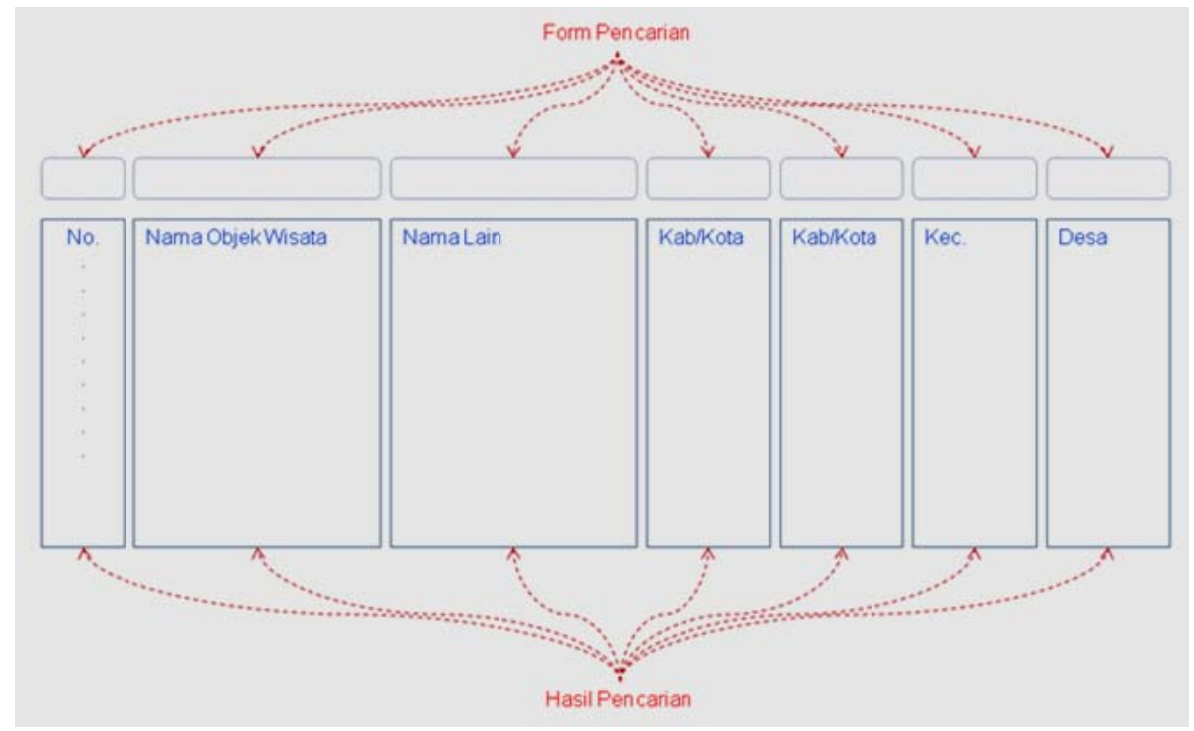

Gambar 5 Tampilan Daftar Objek Wisata dan Form Pencarian 


\title{
Tampilan Informasi Pariwisata
}

Tampilan informasi hasil pengumpulan dan pengolahan Data Tahap I diharapkan seperti di bawah ini:

\author{
Nama Objek wisata: Pantai Indah Turegalökö \\ Nama Lain: $\quad$ Pantai Indah Tureloto
}

\section{Deskripsi:}

Pantai ini terkenal dengan hamparan batu-batu karang yang ada di darat maupun di tengah-tengah laut. Sangat baik cocok untuk melakukan aktifiats berenang di antara batu-batu karang karena airnya tenang bagaikan kolam renang. Snorkeling juga bisa dilakukan asalkan peraltaan dibawa sendiri. Pengunjung juga bisa naik perahu yang tersedia untuk mengeliligi pulau-pulau atau karang-karang di sekitarnya.

Bila datang pada pagi hari bisa menyaksikan aktifitas nelayan dan burung-burung bangau yang sedang menangkap ikan.

\section{Lokasi}

Propinsi: Sumatera Utara

Kabupaten/kota: Nias Utara

Kecamatan: Lahewa

Desa: Balõfadoro Tuho

\section{Fasilitas}

Kamar Bilas \& Tilet Umum

Saung atau Warung

\section{Cara untuk mencapai lokasi objek wisata}

Jarak dari Kota Gunung Sitoli jaraknya sekitara 80 km yang dapat ditempuh kurang lebih 2 jam saja dengan kendaraan roda empat. Dari ibu kota kecamatan Lahewa, yaitu kurang lebih hanya empat kilo meter. Dan dari Kecamatan Lotu, ibukota Kabupaten Nias Utara hanya 25 kilo meter, kurang lebih setengah jam dengan kendaraan roda empat.

\section{Gambar/foto pendukung}
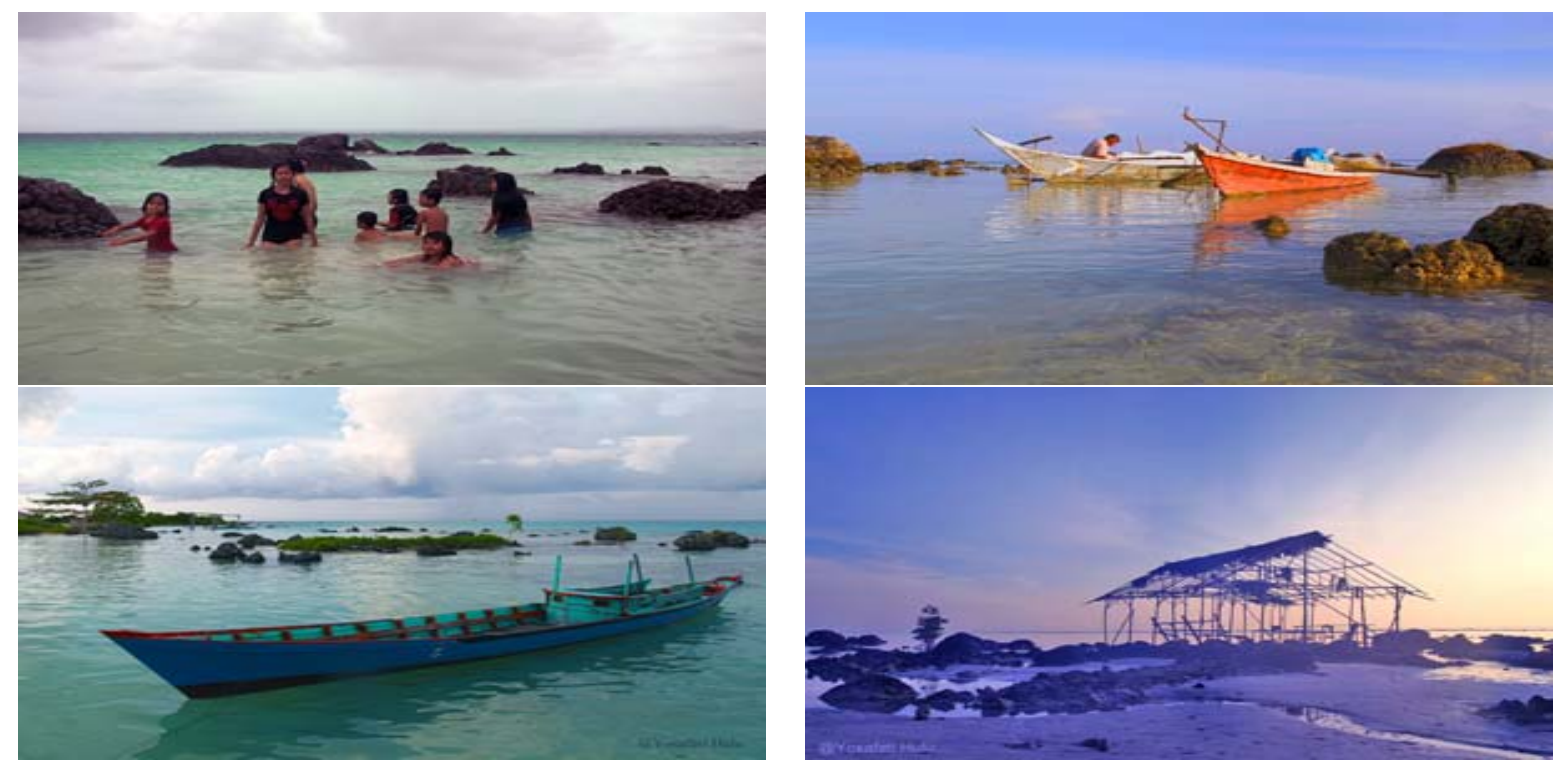


\section{SIMPULAN}

Database Destinasi Pariwisata Indonesia yang dibangun bertujuan: merekam dan menyajikan data dan informasi seluruh destinasi pariwisata di Indonesia secara rinci dan lengkap, mendorong keterlibatan masyarakat lokal dalam menyajikan berbagai hal tentang destinasi pariwisata di daerahnya, dan merekam berbagai pengalaman wisatawan dalam mengunjungi objek wisata tertentu. Jika informasi yang dimasukkan telah lengkap maka media ini akan menjadi sistem informasi objek wisata yang terintegrasi untuk seluruh wilayah Indonesia.

Database yang dibangun bersifat terbuka. Jadi, selain melakukan pengumpulan data dan informasi awal lebih dari seratus destinasi pariwisata di Indonesa, setiap user juga dapat berkonstribusi dalam memasukkan data dan informasi yang relevan pada objek wisata tertentu atau melakukan penambahan destinasi pariwisata baru, sehingga semua destinasi pariwisata di Indonesia diharapkan terekam dalam sistem database ini.

Pengumpulan dan Pengolahan Data Tahap I (dilakukan secara bertahap) untuk menguji apakah sistem sesuai dengan yang diharapkan atau tidak. Hasilnya merupakan cikal bakal Database Pariwisata Indonesia yang lengkap dan juga merupakan contoh pada user yang ingin memasukkan data dan informasi yang relevan pada objek wisata tertentu.

Keakuratan dan Keabsahan informasi akan dijaga atau dijamin dengan memberikan fasilitas verifikasi data dan informasi kepada admin atau moderator yang ditentukan. Pengelompokan informasi dalam media ini dilakukan: (1) Berdasarkan struktur pemerintahan mulai dari provinsi sampai dengan desa. (2) Berdasarkan kategori objek wisata. (3) Berdasarkan kedekatan antar lokasi. Pengelompokan ini menjadi penting karena memberikan kemudahan dan keleluasan bagi user untuk menyimpan, menyajikan, dan mencari objek wisata yang diinginkan. Sistem ini juga menjadi landasan dalam pembangunan Data Warehouse System, Decision Support System, dan Expert System bagi industri pariwisata Indonesia.

\section{DAFTAR PUSTAKA}

Care Tourism. (2010). Visi Pengembangan Destinasi Pariwisata Indonesia. Diakses dari http://caretourism.wordpress.com/2010/06/27/visi-pengembangan-destinasi-pariwisataindonesia/

Departemen Perdagangan Republik Indonesia. (2008). Pengembangan Ekonomi Kreatif Indonesia 2025: Rencana Pengembangan Ekonomi Kreatif Indonesia 2009-2025.

Pangestu, M. E. (2008). Pengembangan Ekonomi Kreatif Indonesia 2025. Disampaikan dalam Konvensi Pengembangan Ekonomi Kreatif 2009-2015 yang diselenggarakan pada Pekan Produk Budaya Indonesia 2008, JCC, 4-8 Juni 2008.

Proll, Birgit and Retschitzegger, Werner. (2008). Discovering Next Tourism Information System: A Tour on TIScover. Journal of Travel research, Pennsylvania State Univ.

Rahardjo, B. (2004). Pemanfaatan Teknologi Informasi dalam Promosi Destinasi Wisata. Diakses dari http://budi.insan.co.id/presentation/IT-pariwisata-2004.ppt

Sharma, N. (2010). Database Fundamentals. IBM Canada.

Silberschatz, A. (2005). Database System Concepts. Mcgraw-Hill Education. 